AperTO - Archivio Istituzionale Open Access dell'Università di Torino

\title{
What makes an urban bird?
}

\section{This is the author's manuscript}

Original Citation:

Availability:

This version is available http://hdl.handle.net/2318/131778

since

Published version:

DOI:10.1111/j.1365-2486.2010.02247.x

Terms of use:

Open Access

Anyone can freely access the full text of works made available as "Open Access". Works made available under a Creative Commons license can be used according to the terms and conditions of said license. Use of all other works requires consent of the right holder (author or publisher) if not exempted from copyright protection by the applicable law. 


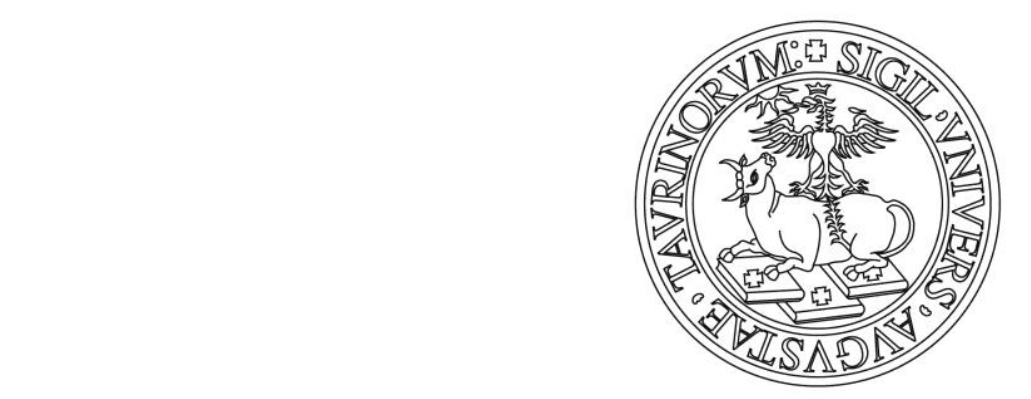

\section{UNIVERSITÀ DEGLI STUDI DI TORINO}

This is an author version of the contribution published on:

Questa è la versione dell'autore dell'opera:

Global Change Biology, 17: 32-44, 2011 10.1111/j.1365-2486.2010.02247.x

The definitive version is available at:

La versione definitiva è disponibile alla URL:

http://onlinelibrary.wiley.com/doi/10.1111/j.1365-2486.2010.02247.x/abstract 
KARL L. EVANS, ${ }^{1 *}$ DAN E. CHAMBERLAIN ${ }^{2 \dagger}$,

${ }^{3}$ Conservation Science, RSPB, The Lodge, Sandy, SG19 2DL, U.K.

*Author for correspondence: K.L. Evans, Department of Animal and Plant Sciences, 
1 Abstract

2 Urban development is increasing across the globe. This poses a major threat to biodiversity,

3 which is often limited in towns and cities. Despite much interest in identifying species' traits

4 that can predict their responses to environmental degradation this approach has seldom been

5 employed to assess which species are particularly vulnerable to urban development. Here, we

6 explore this issue, exploiting one of the best available datasets on species' responses to towns

7 and cities in a highly urbanised region, comprising avian densities across approximately 3,000

8 British urban and rural $1 \mathrm{~km} \times 1 \mathbf{k m}$ grid cells. We find that the manner in which species'

9 responses to urbanisation is measured has a marked influence on the nature of associations

10 between these responses and species' ecological and life history traits. We advocate that

11 future studies should use continuous indices of responses that take relative urban and rural

12 densities into account. Contrary to previous studies we find that urban development does not 13 select against avian long-distance migrants and insectivores, or species with limited annual

14 fecundity and dispersal capacity. There was no evidence that behavioural flexibility, as measured by relative brain size, influenced species' responses to urban environments. In Britain, generalist species, as measured by niche position rather than breadth, are favoured by urban development as are, albeit to a lesser extent, those that feed on plant material and nest above the ground. Our results suggest that avian biodiversity in towns and cities in

20 scarce in urban areas, encouraging supplementary feeding, and developing suitable 21 environments for ground-nesting species.

23 Key words: birds, brain size, cities, development, predation, specialist, species traits, urbanisation 24 index 
1 Globally, urbanisation is amongst the fastest growing land uses (UN, 2008). This is partly due to

2 human population growth, but also arises from socio-economic factors that result in people moving

3 from rural to urban areas, a greater proportion of single person households, and elevated demand for

4 low density housing (Liu et al., 2003; UN, 2008). Increased urban development has a negative

5 impact on biodiversity for three main reasons. First, urbanisation is most likely to occur in regions

6 that contain large numbers of people; this results in conservation conflicts because, at broad spatial

7 scales, human population density is positively correlated with species richness (Evans et al., 2006,

8 2007; Luck, 2007). Second, the land selected for housing development is often more ecologically

9 valuable than undeveloped areas (Bartlett et al., 2000; Gonzalez-Abraham et al., 2007; Radeloff et

10 al. in press). Third, highly developed urban areas support fewer native species than the rural

11 habitats which they replace; indeed, many species do not occur in urban areas despite being present

12 in nearby rural habitats (Tratalos et al., 2007; Grimm et al., 2008). These reductions in biodiversity

13 are increased because there is limited spatial turnover in the composition of urban assemblages, i.e.

14 urbanisation promotes biotic homogenization (McKinney, 2006; Devictor et al., 2007).

16 Urban development is thus a major threat to conservation (Czech et al., 2000; McDonald et al., 17 2008), and it is important to assess which ecological and life history traits predict species' responses 18 to urbanisation. A small number of initial investigations have been conducted that classify species 19 into two groups that differ in their response to urbanisation, such as those that occur or reproduce in 20 cities and those that do not, and then assess how species' traits differ between the two groups 21 (Bonier et al., 2007; Kark et al., 2007; Croci et al., 2008; Møller, 2009). Such studies are severely 22 limited because they assume that all species within a group have an equivalent response to 23 urbanisation. This is highly unlikely to be valid as species vary in their urban densities, and the 24 types of urban areas in which they occur (Tratalos et al., 2007; Grimm et al., 2008; Evans et al., 25 2009). Here, we provide a rare assessment of associations between species' traits and responses to 26 urban development. In notable improvements to previous studies we measure species' responses 
1 using a continuous quantitative index, and assess how the nature of associations between species'

2 traits and responses to urbanisation depend on the precise form of these urbanisation indices. We

3 start, however, by assessing which ecological and life history traits are likely to influence a species'

4 ability to thrive in urban areas; this will be determined by successful progression through each of

5 the three phases of biotic urbanisation, i.e. arrival, adjustment and spread (Evans et al., in press).

7 Species vary widely in their environmental tolerances, and generalists appear less vulnerable to 8 habitat deterioration and loss (Owens \& Bennett, 2000; Shultz et al., 2005), including urban 9 development (Bonier et al., 2007; Kark et al., 2007). Behavioural flexibility may also help species 10 tolerate environmental change. Measurements of flexibility, such as the acquisition of new foraging 11 techniques, are correlated with relative brain size (Lefebvre et al., 1997, 1998; but see Healy \& 12 Rowe, 2007), which can predict the magnitude and direction of population trends in response to 13 environmental degradation (Shultz et al., 2005), and which species invade novel environments (Sol 14 et al., 2005, 2008). Therefore, urbanisation may also promote behaviourally flexible species with 15 relatively larger brains.

17 Long distance migrants are declining more rapidly than residents, and may be more vulnerable or 18 more exposed to environmental change (Sanderson et al., 2006; Wilcove \& Wikelski, 2008); they 19 also appear to be scarcer in urban areas than residents (Friesen et al., 1995; Rodewald \& 20 Bakermans, 2006). This may be because migrants are disadvantaged when competing for limited 21 resources as they tend to arrive on breeding grounds after residents have established territories. 22 Migrants also appear more susceptible to mismatches between the timing of breeding and peak food 23 availability induced by climate change (Visser et al., 2004; Post \& Forchhammer, 2008); the urban heat island effect (Collier, 2006) may thus make developed areas less suitable for migrants. 
1 Within urban areas green space is highly fragmented, thus dispersal may result in arrival in

2 unsuitable environments more frequently than if individuals remained in their current habitat patch;

3 reduced dispersal capacity can thus be advantageous in cities (Cheptou et al., 2008). This advantage

4 may also arise because frequent dispersal can generate sufficient gene flow between populations

5 occupying contrasting environments to swamp locally evolving adaptive genotypes, thus preventing

6 genetic adaptation to novel conditions, including those occurring in urban areas (Rasanen \&

7 Hendry, 2008; Rios et al., 2008). In contrast, strong dispersal capacity increases the probability of a

8 species colonising novel environments (Lloret et al., 2005; Philips et al., 2008), and recolonising

9 previously occupied habitat patches following local extinction (Hanski, 2001). It is thus generally

10 considered that, and despite the contrary hypotheses, species which have successfully colonised

11 urban areas are likely to have strong dispersal abilities (Møller, 2009).

13 Adjustment to novel urban environments may require genetic change (Partecke et al., 2006; Rios et $14 a l ., 2008)$. In sexually reproducing species the potential rate of such change is positively influenced 15 by short generation times and the production of a large number of offspring, as these determine the 16 number of meiosis events and thus the potential for DNA copying errors (i.e. mutations). These 17 demographic traits also generate high intrinsic population growth rates which may enable rapid 18 recovery from disturbance, and produce more potential colonists. These mechanisms may explain 19 why fecund species appear less vulnerable to environmental degradation (Owens \& Bennett, 2000; 20 Purvis et al., 2000).

22 Urban areas are often characterised by the provision of supplementary avian food, which 23 predominantly consists of seeds or other plant material (Davies et al., 2009). Therefore, species 24 which can exploit such food sources may be more abundant in urban areas than those with 25 alternative diets (Fuller et al., 2008); indeed insectivorous species appear to be relatively scarce in 26 urban areas (Chace \& Walsh, 2006; Kark et al., 2007). 
2 Finally, predation risk may be greater in urban areas due to changes in habitat types (Riley et al.,

3 2005, Hamer \& McDonnell, 2008), or higher densities of some predators such as domestic cats

4 Felis catus and nest predating corvids (Sims et al., 2008; Evans et al., 2009). It is often suggested

5 that bird species which nest on or close to the ground will be adversely impacted by urbanisation

6 due to increased nest predation (Jokimäki \& Huhta, 2000, Chace \& Walsh, 2006, Croci et al.,

7 2008). In contrast, a recent review concludes that across those species which occur in towns and

8 cities urbanisation does not consistently markedly alter avian nest predation rates (Chamberlain et

9 al., 2009). However, when considering a wider range of species it remains plausible that those

10 which are vulnerable to predation because they nest on the ground will be adversely influenced by

11 urbanisation.

13 Here we assess the hypotheses that avian species which have (i) broad ecological requirements; (ii)

14 relatively large brains; (iii) resident populations, (iv) strong dispersal capacities, (v) high fecundity,

15 (vi) a plant-based diet, and (vii) do not nest close to the ground are more likely to be urbanised than

16 species which lack these traits. In so doing, we provide the first assessment of whether the nature of

17 associations between species' traits and responses to urban areas varies with the form of

18 urbanisation indices. Specifically, we compare indices constructed using different definitions of

19 urban land, and which do and do not take species' rural abundances into account. We use the British

20 avifauna as a case study for three reasons. First, the national Breeding Bird Survey (BBS) enables

21 population densities to be calculated for specific habitat types. We can thus develop urbanisation

22 indices along a continuous scale, a notable advance on previous studies that typically classify

23 species on a binary, and somewhat subjective, scale as urbanised or not. Second, detailed data on

24 the ecological and life history traits of British birds are available that enable more rigorous tests of

25 associations between species' traits and urbanisation than previously possible. Finally, Britain has a

26 long history of urban development and is now amongst the most highly urbanised regions (with 
1 between $8 \%$ and $10 \%$ of the land area being urban, Haines-Young et al., 2000; Fuller et al., 2002).

2 Our analyses thus facilitate prediction of which species are likely to thrive, and which to be

3 threatened, in regions that are currently less urbanised but are experiencing rapid urbanisation.

\section{Methods}

\section{$6 \quad$ Urbanisation indices}

7 For each of 88 commoner and accurately surveyed? native breeding bird species recorded in the 2006 BBS (Raven et al., 2007) the urbanisation index was first calculated as the density in urban areas. Species may, however, occur at low densities in urban environments because their ecological characteristics are such that they have a large home range and thus always occur at low densities,

11 irrespective of habitat type, rather than because urban environments are particularly unsuitable. We 12 therefore also calculated another urbanisation index as the ratio of urban and rural densities. We 13 used two definitions of urban areas that varied in the proportion of built up land in the focal area 14 (see below), thus giving four different urbanisation indices.

A full description of the BBS survey methodology is provided in Appendix A. In brief, distance 17 sampling was conducted along ten $200 \mathrm{~m}$ transect sections in a randomly selected $1 \mathrm{~km} \mathrm{x} 1 \mathrm{~km}$ 18 square. The main habitat, such as human sites or woodland, in each section was recorded together 19 with finer level habitat features (Crick, 1992). We defined urban BBS squares in two ways. First, 20 those in which the primary habitat type in each of the ten transect sections was classified as urban or 21 suburban; 153 of 3002 squares met this criterion. Second, those with at least six urban or suburban 22 transect sections; 272 squares met this criterion. Urban squares are located throughout the focal 23 region, and remaining squares were considered to be rural. The density of adult breeding birds was 24 determined using the methodology of Newson et al. (2008). 
1 Data on species traits were obtained for British populations from Cramp et al. (1977-1994) unless

2 otherwise stated (Appendix B). These data are typically derived from studies conducted in relatively

3 natural environments. Annual fecundity was calculated as the mean number of clutches per year

4 multiplied by the mean clutch size. Species were classified as nesting close to the ground if they

5 typically nested on or just above the ground. We recorded whether invertebrates or plant material

6 comprised major components of adult diets during the breeding season using two binary factors,

7 thus omnivorous species were coded as using both food sources. Using Wernham et al. (2002),

8 species were classified as long distance migrants if the majority of the population wintered south of

9 the Sahara, and as residents if the majority wintered in Britain. Arithmetic mean natal dispersal

10 distance of British birds was obtained for 61 species from Paradis et al. (1998). We used natal

11 rather than breeding dispersal distance as the former was available for more species. Paradis et al.

12 (1998) calculated both arithmetic and geometric mean dispersal distances, but the two are strongly

13 correlated (Spearman rank correlation $\mathrm{r}_{\mathrm{s}}=0.93, \mathrm{n}=63, P<0.0001$ ), and we arbitrarily decided to

14 use the former. We logarithmically transformed natal dispersal distance to base ten to reduce the

15 skew in its distribution.

17 Brain size can be measured as either endocranial volume or brain mass, and the two are very 18 strongly correlated (Iwaniuk \& Nelson, 2002). We obtained data on endocranial volume $\left(\mathrm{mm}^{3}\right)$ for 1951 species that were obtained by filling the brain cavity, of unfractured skulls from apparently 20 healthy adults, with a 50:50 mixture of sizes 10 and 11 lead shot, which yields highly repeatable 21 measurements (Iwaniuk \& Nelson, 2003; A. Iwaniuk, unpublished data). We also obtained brain mass data for 81 species from Mlíkovský (1989a-c, 1990). These data were converted to volumes 23 using the widely accepted value of the density of fresh avian brain tissue $(1.036 \mathrm{~g} / \mathrm{ml}$; Ebinger, 24 1995; Iwaniuk \& Nelson, 2001). The resultant two data sets were strongly correlated $\left(\mathrm{r}^{2}=0.987, P\right.$ $25<0.0001, \mathrm{n}=49$; linear regression of data logarithmically transformed to base ten) and a paired $\mathrm{t}$ 26 test showed there were no significant differences between them $(T=-0.01, P=0.989, \mathrm{n}=49)$. 
1 When brain size data were available from both sources we used the average value, but otherwise

2 used information from a single source, thus providing data for 83 species. Brain size scales with

3 body size and this allometric relationship must be taken into account when assessing the influence

4 of brain size on species' ecological responses. The inclusion of both variables in the allometric

5 relationship, i.e. brain size and body size, as predictors in a single multiple regression analysis

6 provides the ideal method for assessing the influence of the focal variable, i.e. relative brain size

7 (Freckleton, 2002). We adopted this approach using mean body mass data from the compilation in

8 Gaston \& Blackburn (2000) and logarithmically transformed both brain volume and body mass

9 data, to base ten, to reduce the skew in their distributions. Previous studies have taken the allometry

10 between brain and body size into account using residuals from a log-log regression of brain size

11 against body size as a measure of relative brain size, but the use of such residuals as predictors in

12 further analyses can generate biased parameter estimates and should be avoided (García-Berthou,

13 2001; Freckleton, 2002).

15 Due to the multi-dimensional nature of niche space we used two approaches to classify species 16 along the continuum from specialists to generalists. First, geographic range size has previously been 17 used as a measure of environmental tolerance under the assumption that possessing a large range 18 requires adaptation to a wide variety of environmental conditions. This may not be valid in all 19 situations, as a species may occur widely but use only a few habitat types within its range, but 20 validity will be maximised when range size is measured as area of occupancy, rather than extent of 21 occurrence, and will increase as spatial grain size becomes smaller (Gaston, 2003). Therefore, we 22 calculated the number of European $50 \mathrm{~km}$ x $50 \mathrm{~km}$ grid cells occupied by each species during the 23 breeding season from Hagemeijer \& Blair (1997). Following Gregory et al. (1998) we excluded the 24 far east of the surveyed region as survey coverage in these areas was typically limited. Hagemeijer 25 \& Blair (1997) do not distinguish between Carduelis flammea and C. cabaret. Only C. cabaret 
1 breeds in Britain, and we estimated its range size from Hagemeijer \& Blair (1997) using the

2 description of its distribution in Clement et al. (1993).

4 Second, and in reflection of the multi-dimensional nature of niche space, we obtained data on niche

5 breadth and niche position, which are two complementary measures of specialisation (Shugart \&

6 Patten 1972). Niche breadth measures a focal species' tolerance to contrasting environmental

7 conditions. Niche position measures how typical the resource use of a particular species is relative

8 to all other species and the resources available; species with a large niche position thus use less

9 typical resources (Shugart \& Patten 1972). Following the methodology of Gregory \& Gaston

10 (2000), who previously calculated niche breadth and position of British birds, we calculated niche

11 breadth and position using a canonical correspondence analysis (CCA). The major change that we

12 implemented compared to Gregory \& Gaston (2000) was that we excluded environmental variables

13 that described the magnitude of urbanisation from the calculations of niche metrics, thus leaving a

14 total of 29 environmental variables (Table 1). We also implemented three further minor changes: (i)

15 avian abundance data were from 2006, (ii) climatic data were updated to include more recent years,

16 which required the use of cloud cover rather than sunshine hours, and (iii) land-cover classifications

17 of $1 \mathrm{~km}$ squares were updated. The standard deviation of each species' distribution of tolerance

18 across each axis identified by the CCA provides estimates of niche breadth, and the root mean

19 squared standard deviations across all four axes provides an overall estimate of niche breadth.

20 Niche position is calculated as the distance of the centroid of a species from that of the whole

21 assemblage, which is calculated as the mean of the coordinates of the species' centroids. Niche

22 position was logarithmically transformed to base ten to reduce the skew in its distribution. The

23 niche breadth and position data calculated by Gregory \& Gaston (2000) were strongly correlated

24 with our newly calculated data (niche breadth: $\mathrm{r}=0.900, P<0.0001$; $\log _{10}$ niche position: $\mathrm{r}=0.842$,

$25 P<0.0001 ; \mathrm{n}=77$ in both cases). 
2 Analyses were conducted in SAS vs 9.1. Whilst our four measures of urbanisation were strongly

3 correlated (Table 2), initial analyses suggested that they may differ in the nature of their relationship

4 with species traits. We thus assessed the relationship between species' urbanisation indices and

5 traits using each of the four indices. Prior to analysis each index was logarithmically transformed to

6 base ten, after adding 0.1 to all values (to ensure that indices of species that did not occur in urban

7 areas could be transformed). For each continuous predictor we assessed if including the square term

8 improved the fit, measured using AIC values, of a linear bivariate model. This was the case only for

9 logarithmically transformed niche position, and its square term was thus included as an additional 10 predictor.

12 We conducted multiple regression analyses and, following standard protocols, adopted the 13 information theoretic approach to model simplification (Burnham \& Anderson, 2002). All possible 14 models given the set of predictor variables were constructed, models with lower AIC values are considered more parsimonious. We calculated model weights, the probability that a model provides the most parsimonious fit to the data, and then constructed the $95 \%$ confidence set of models as that

17 with the smallest number of models whose cumulative weights summed to 0.95 . We assessed the 18 explanatory power of each predictor using model averaging over the 95\% confidence set. For each 19 response variable we first constructed multiple regression models for all 88 species but excluded the 20 predictors for which data were missing for some species, i.e. relative brain size, natal dispersal, 21 niche breadth and niche position (linear and quadratic terms), leaving six predictors and 63 possible models. We then constructed an additional set of models that used data for the 55 species for which 23 data were available for all our predictors (11 predictors and 2047 models). For both sets of models 24 the tolerance values of all predictors (analysis of all species, range $0.61-0.82$; analysis of all 25 predictors, range $0.29-0.74)$ were consistently above the threshold $(0.1)$ at which colinearity 26 becomes a major concern (Quinn \& Keough, 2002). 
2 Analyses were first conducted assuming that each species provided independent data. We then used

3 phylogenetic generalised least squares (PGLS; Grafen, 1989; Martins, 1999; Garland \& Ives, 2000)

4 to test for non-independence arising from shared evolutionary history. PGLS explicitly incorporates

5 the expected covariance among species into a statistical model fit. The correlations between error

6 terms are thus altered to reflect the magnitude of phylogenetic relatedness amongst species. The

7 PGLS approach was implemented in R, using the Analysis of Phylogenetics and Evolution (APE)

8 package (Paradis et al., 2004) and the phylogeny of Thomas (2008). This phylogeny excludes one

9 of our focal species, coot Fulica atra, which was thus excluded from the PGLS analysis. PGLS

10 generates a metric $(\lambda)$ which varies from zero (no phylogenetic autocorrelation) to one (strong

11 phylogenetic autocorrelation).

\section{Results}

14 Phylogenetic constraints

15 PGLS analyses demonstrated that $\lambda$ was not significantly different from zero when modelling any of 16 our response variables $(P>0.6$ in all cases), and changes to parameter estimates were negligible. 17 Phylogenetic correlation in these data is thus very low and analyses that treat species as independent 18 data points are justified.

\section{Urban densities}

21 Analyses of species densities in urban environments, conducted across all focal species, generate remarkably consistent results whether those densities are calculated across highly urbanised squares

23 (i.e. those in which each of the ten $200 \mathrm{~m}$ transect sections are located in urban or suburban environments), or when moderately urbanised squares (i.e. those with six or more transect sections in urban or suburban environments) are included (Table 3a). Species' ecological and life history 
1 with the largest explanatory capacity is European geographic range size, which correlates positively

2 with urban density (model averaged partial $r^{2}=0.23$ for both density metrics; Table 3a, Fig. 1a).

3 The explanatory capacity of two other predictor variables is greater or equal to $5 \%$. Species have

4 higher urban densities if they include plant material in their diet (model averaged partial $r^{2}=0.08$

5 and 0.07 when urban squares are respectively defined as moderately and highly urbanised ones),

6 and if they are not long distance migrants (model averaged partial $r^{2}=0.05$ for both density metrics,

7 Table 3a).

9 In analyses that focus on the 55 species for which data were available for all predictors, species 10 traits can again explain approximately $50 \%$ of the variation in urban densities (Table $3 \mathrm{~b}$ ). In these 11 models higher urban densities are associated with species that use resources which are common in 12 the environment, i.e. have a low niche position (partial $r^{2}=0.25$ and 0.18 when urban squares are 13 respectively defined as moderately or highly urbanised ones; Table $3 b$, Fig $2 c)$. To a lesser extent 14 high urban densities are also associated with species that feed on plant material (partial $r^{2}=0.09$ 15 and 0.07 when urban squares are respectively defined as moderately or highly urbanised ones; 16 Table 3b). The explanatory capacity of all other predictor variables was less than 5\%.

\section{Urban/rural density ratios}

19 In analyses conducted across all species, ecological and life history traits can explain approximately

$2030 \%$ of the variation in the ratio of urban and rural densities; results are again consistent with regard

21 to the definition of urban squares (Table 3a). The reduced explanatory power of the ratio indices 22 does not appear to arise from reduced variation in the response variables as both response variables 23 have similar coefficients of variation (moderately urbanised squares: density index, 2.55; ratio 24 index, 2.38; highly urbanised squares: density index, 2.74; ratio index, 3.09). The traits associated 25 with the ratio urbanisation index differ notably from those that explain variation in species' urban 26 densities. The most marked difference is that the size of a species' European geographic range is no 
1 longer strongly associated with urbanisation (partial $r^{2}$ is consistently $<0.01$; Table $3 a$, Fig. 1b); the

2 same also applies to migratory status (partial $r^{2} \leq 0.01$; Table 3a). Species tend to have higher

3 densities in urban areas than rural ones if they do not nest on or close to the ground (partial $r^{2}=0.08$

4 and 0.10 when urban squares are respectively defined as moderately or highly urbanised ones;

5 Table 3a), and when their diet includes plant material (partial $r^{2}=0.10$ for both ratio indices; Table $63 a)$.

8 In analyses conducted on the restricted set of species, their traits can explain approximately $40 \%$ of 9 the variation in the ratio index of urbanisation (Table 3b). Species with higher urban to rural 10 densities have lower niche positions (partial $r^{2}=0.20$ and 0.14 when urban squares are respectively 11 defined as those with six and ten urban/suburban transect sections; Table 3b, Fig 1d), and tend to 12 include plant material in their diet (partial $r^{2}=0.10$ and 0.09 respectively for moderately and highly 13 urbanised squares; Table $3 b$ ). Partial $r^{2}$ values were less than 0.02 for all other predictors.

\section{Discussion}

16 The lack of phylogenetic signal in the urbanisation indices is not surprising given that a number of

17 closely related avian species differ markedly in the extent to which they are urbanised in Britain.

18 For example, turtle dove Streptopelia turtur, tree sparrow Passer montanus and rook Corvus 19 frugilegus occur predominantly in rural areas, whilst congeneric species (collared dove Streptopelia 20 decaocto, house sparrow Passer domesticus, and carrion crow Corvus corone) are highly urbanised 21 (Evans et al., 2009).

23 The species traits associated with urbanisation indices were consistent regardless of whether urban areas were defined as those that contained only highly developed areas, or when moderately developed areas were also included. In contrast, whether urbanisation indices were constructed using species' urban densities or the ratio of urban to rural densities had a marked influence on their 
1 associations with species' traits, especially when analyses were conducted across all species.

2 Urbanisation indices must thus be carefully designed to suit the aims of a particular study. We

3 suggest that the ratio of urban and rural densities is generally the most appropriate metric for

4 assessing responses to urban development. This is because associations between urban densities and

5 species' traits may arise either because the traits influence a species' ability to cope with

6 urbanisation, or because they are linked with traits that generally influence population density.

7 Binary classifications of whether species are urbanised or not are commonly used, but they do not

8 take relative rural and urban densities into account, and are further limited by their assumption that

9 all species which occur in towns and cities have equivalent responses to urban development.

11 European range size provides a good example of how the nature of the urbanisation index alters

12 relationships with species' traits. Whilst range size is positively associated with species' urban

13 densities and the occurrence of species in urban areas (Table 4, as previously reported by Bonier et 14 al., 2007 and Møller, 2009), there is a negligible link between range size and the ratio of urban and 15 rural densities. This contrast probably arises because species with large ranges are common in both 16 urban and rural environments, as implied by the frequently documented positive interspecific 17 abundance-range size relationship (Gaston et al., 1998). Moreover, the finding that the ratio of 18 urban to rural densities cannot be predicted by range size suggests that the latter provides relatively 19 little information regarding how a species' density is likely to change in a rural area that 20 subsequently becomes urbanised. This lends support to our suggestion that urban to rural density 21 ratios provide a preferable metric of species' responses to urbanisation than either their urban 22 densities in isolation or presence/absence in towns and cities.

24 Similarly, we find only limited evidence that long distance migrants have lower urban densities, and migratory status has a very negligible influence on the ratio of urban and rural densities. Whilst this appears to contradict previous suggestions that long-distance migration hinders a species' ability to 
1 thrive in urban areas (Friesen et al., 1995; Kark et al., 2007; Croci et al., 2008) it is partly a

2 consequence of previous studies' use of binary indices of species responses to urban development.

3 If we use an equivalent approach, species present in moderately urbanised squares are less likely to

4 be long-distance migrants than expected by chance $\left(\chi^{2}=9.31\right.$, df $\left.=1, P<0.001\right)$, although

5 migratory status does not influence occurrence in highly urbanised squares $\left(\chi^{2}=3.21\right.$, df $=1, P>$ $6 \quad 0.05)$.

8 Møller (2009) found that avian species occurring in European urban areas had greater dispersal

9 ability than those absent from towns and cities; while we found no association between urbanisation

10 indices and dispersal. However, it is difficult to compare the two studies directly due to differences

11 in the conceptual approach (we used continuous indices of urbanisation rather than binary

12 classifications), variation in the focal species, and in some cases differences in classification of

13 species; for example, Møller (2009) classifies carrion crow Corvus corone and wren Troglodytes

14 troglodytes as absent from European urban areas, but in Britain their mean urban densities are

15 respectively $22.7 \mathrm{~km}^{-2}$ and $25.3 \mathrm{~km}^{-2}$ (Evans et al. 2009). Measures of dispersal also differed

16 between the studies; we used data from intensive ringing studies, whilst Møller (2009) used

17 surrogate measures, i.e. the number of described subspecies and maximum distance between a

18 species' island and mainland populations. We removed the first of these differences by conducting

19 bivariate analyses of differences in dispersal distances in species that did and did not occur in at

20 least one of our focal urban BBS squares. The lack of association between dispersal ability and

21 occurrence in highly urbanised areas remained, whilst species occurring in moderately urbanised

22 areas tended to have shorter dispersal distances than non-urbanised species (Table 4), which is the

23 opposite pattern to that found by Møller (2009). It thus appears that in highly urbanised parts of

24 Europe, such as Britain, dispersal capacity has a limited influence on species' responses to urban

25 development. Dispersal ability may play a more prominent role in promoting urban colonisation in 
1 regions where development has occurred less frequently and more recently, thus reducing the

2 number of potential sites and the time available for urban colonisation.

4 Annual fecundity was not associated with our urbanisation indices, even when classifying species as 5 present/absent in urban areas (Table 4). This contrasts with previous studies reporting higher 6 fecundity in urbanised species (Croci et al., 2008; Møller, 2009), and the extent to which high 7 fecundity generally promotes the establishment of urban populations is thus unclear.

9 We found strong evidence that specialists, as assessed by niche position, had lower urban densities 10 and ratios of urban to rural densities than more generalist species. There was no association between 11 urbanisation and niche breadth. Therefore, whilst other work suggests that urbanisation promotes 12 generalist species, contributing to biotic homogenisation (McKinney, 2006; Bonier et al., 2007; 13 Kark et al., 2007; Møller, 2009), our results indicate that such patterns depend on the precise 14 definition of specialisation. Indeed, whilst niche breadth is a commonly used index of specialisation 15 many studies find that niche position is a strong predictor of ecological patterns, and can be a better 16 predictor than niche breadth (Gregory \& Gaston, 2000; Shultz et al., 2005; Hurlbert \& White, 2007; 17 Ranap et al., 2009).

19 We found no evidence that relative brain size is associated with a species' ability to adapt to urban 20 environments, thus concurring with Kark et al. (2007). An alternative measure of behavioural 21 flexibility is the number of novel feeding behaviours documented for a species. This metric is 22 sometimes positively associated with avian occurrence in urban areas (Møller, 2009; but see Kark et 23 al., 2007), but the causal nature of this relationship is uncertain as in urban areas birds may 24 encounter more novel food sources, and thus have greater potential to exhibit novel feeding 25 behaviours. 
1 Urbanisation appears to select against insectivorous species (Chace \& Walsh, 2006; Kark et al.,

2 2007), but we found no evidence that species which included invertebrates in their adult diet had

3 lower urban densities, or lower ratios of urban and rural densities. It is possible that this contrast

4 arises because we include species that feed on terrestrial invertebrates, such as earthworms

5 (Lumbricidae), as insectivores. To test this we constructed full models (using the predictors retained

6 in the $95 \%$ confidence set of models) in which insectivorous species were defined as those that

7 gleaned invertebrates from vegetation, but such models still yielded little evidence that this trait was

8 associated with urban densities or urban and rural density ratios (maximum partial $r^{2}$ value $<0.02$ ).

9 There was a tendency for species that included plant material in adult diets to have higher urban

10 densities and urban to rural density ratios, than species which did not. This supports earlier work

11 suggesting that urbanisation favours granivorous species (Chace \& Walsh, 2006; Kark et al., 2007),

12 presumably because they benefit from supplementary feeding in urban areas (Jokimäki et al., 2002;

13 Fuller et al., 2008).

In analyses conducted across all species, those that did not nest on or close to the ground tended to have higher urban to rural densities than ground-nesting species. Ground-nesting species tend to be

17 open cup nesters, which typically experience higher predation rates than cavity nesting species 18 (Martin \& Li, 1992). In additional bivariate analyses we found no evidence that any of our 19 urbanisation indices were associated with cavity nesting (partial $r^{2}<0.01$ for all urbanisation 20 indices). Thus the association between ground-nesting and urbanisation in our data is not 21 confounded with cavity nesting. Our results are comparable to the finding that ground nesting 22 species are disadvantaged in French cities (Croci et al., 2008). Whilst the reduced ability of ground23 nesting bird species to thrive in urban areas may arise from increased predation risk, there is little 24 evidence for a universal increase in predation risk in urban areas (Chamberlain et al., 2009). Also, 25 in analyses that take specialisation into account using niche metrics ground-nesting has no influence 26 on species' urban to rural density ratios. We thus suggest that urbanisation may select against 
1 ground-nesting species because it reduces the availability of their preferred habitat types in addition

2 to altering predation rates.

\section{Conclusions and implications}

5 The total explanatory capacity of multiple regression models for the level of urbanisation of birds in

6 Britain is higher (range of 28\% to 56\%) than that typically found in many ecological studies (Møller

7 \& Jennions, 2002), but is comparable to previous assessments of associations between species'

8 traits and responses to other types of global change (Shultz et al., 2005; Jiguet et al., 2007; Seoane

$9 \&$ Carrascal, 2008). The nature of associations between urbanisation indices and species' traits

10 varies markedly with how responses to urbanisation are measured; future studies should pay close

11 attention to this issue. We advocate that indices assessing relative urban and rural densities are

12 preferable to the alternatives of using binary classifications of whether species are urbanised or not,

13 which have been the focus of most other previous studies, or urban densities in isolation.

15 Britain has experienced profound habitat modification, but this has not resulted in marked 16 alterations to the species composition of the regional avifauna during the last few centuries 17 (Holloway, 1996; Stewart, 2004). Our results are thus unlikely to be biased by prior extinctions of 18 species with certain ecological or life history traits. Britain is, however, amongst the most urbanised 19 regions and the challenge remains of assessing how species' traits influence responses to urban 20 development in non-avian taxa and in regions with divergent urban development patterns. Previous 21 studies of avian species' responses to urban development have primarily been conducted in Europe and thus concern regions with similar levels of urbanisation to Britain. Despite this similarity our

23 results differ markedly from these other studies as we find little evidence that urban development 24 selected against insectivores, avian migrants, and species with low annual fecundity and limited 25 dispersal ability. In some cases these differences probably arise, at least in part, due to differences 26 in how urbanisation indices are calculated. We find support for the hypothesis that generalist 
1 species are better adapted to urban areas than specialists, although this is dependent upon the

2 precise definition of specialisation. Whilst explanatory power is more limited, our results also

3 suggest that urbanisation favours species that feed on plant resources and that nest above the

4 ground. In regions that are becoming highly urbanised, avian biodiversity in towns and cities may

5 be increased by maximising the availability of scarce resources, encouragement of supplementary

6 feeding, and increasing the suitability of urban areas for ground nesting species. The latter could 7 necessitate both habitat creation, and management of predation risk.

9 Acknowledgements

10 We thank the thousands of volunteers who took part in the Breeding Bird Survey, which is jointly

11 funded by the British Trust for Ornithology, the Joint Nature Conservation Committee (on behalf of 12 the Countryside Council for Wales, English Nature, Scottish Natural Heritage and the Department 13 of the Environment for Northern Ireland) and the Royal Society for the Protection of Birds. Land 14 cover data derived from the LCM2000 data base and Land Characteristics data were provided by 15 the Centre for Ecology and Hydrology. Climate data were derived from United Kingdom Climate 16 Projections 2009 (UKCP09). A. Iwaniuk provided brain size data. F. Bonier, A. Cannon, S. 17 Eglington, R. Freckleton, J. Jokimäki, S. E. Newson, S. Shultz and T. Webb provided discussion 18 and assistance. KLE was supported by the Natural Environment Research Council and the 19 Leverhulme Trust; KJG holds a Royal Society-Wolfson Research Merit Award.

\section{$21 \quad$ References}

Ball DF, Radford GL, Williams WM (1983) A land characteristic data bank for Great Britain: Occasional Paper No. 13. Institute of Terrestrial Ecology, Bangor.

Bartlett JG, Mageean DM, O'Connor RJ (2000). Residential expansion as a continental threat to US coastal systems. Population and Environment, 21, 429-468. 
1 Bonier F, Martin PR, Wingfield JC (2007) Urban birds have broader environmental tolerance.

2 Biology Letters, 6, 670-673.

3 Burnham KP, Anderson DR (2002) Model selection and multimodel inference: a practical 4 information-theoretic approach. Springer, New York.

5 Chace JF, Walsh JJ (2006) Urban effects on native avifauna: a review. Landscape and Urban $6 \quad$ Planning, 74, 46-49.

7 Chamberlain DE, Cannon AR, Toms MP, Leech DI, Hatchwell BJ, Gaston KJ (2009) Avian 8 productivity in urban landscapes: a review and meta-analysis. Ibis, 151, 1-18.

9 Cheptou P-O, Carrue O, Rouifed S, Cantarel A (2008) Rapid evolution of seed dispersal in an urban 10 environment in the weed Crepis sancta. Proceedings of the National Academy of Sciences USA, $11 \quad \mathbf{1 0 9}, 3796-3799$.

12 Clement P, Harris A, Davis J (1993) Finches and sparrows: an identification guide. Christopher 13 Helm, London.

14 Collier CG (2006) The impact of urban areas on weather. Quarterly Journal of the Royal 15 Meteorological Society, 132, 1-25.

16 Cramp S, Simmons KEL, Perrins CM (1977-1994) Handbook of the Birds of Europe, the Middle 17 east and North Africa Vols 1-9. Oxford University Press, Oxford.

18 Crick, HQP (1992) A bird habitat coding system for use in Britain and Ireland incorporating aspects of land-management and human activity. Bird Study, 39, 1-12.

20 Croci S, Butet A, Clergeau P (2008) Does urbanization filter birds on the basis of their biological 21 traits? The Condor, 110, 223-240.

22 Czech B, Krausman PR, Devers PK (2000). Economic associations among causes of species 23 endangerment in the United States. BioScience, 50, 593-601

24 Davies ZG, Fuller RA, Loram A, Irvine KN, Sims V, Gaston KJ (2009) Urban domestic gardens 25 (XV): the extent of the resource at a national scale. Biological Conservation, 142, 761-771. 
1 Devictor V, Julliard R, Couvet D, Lee A, Jiguet F (2007). Functional homogenization effect of

2 urbanization on bird communities. Conservation Biology, 21, 741-751.

3 Ebinger P (1995) Domestication and plasticity of brain organization in mallards (Anas 4 platyrhynchos). Brain, Behavior and Evolution, 45, 286-300.

Evans KL, Greenwood JJD, Gaston KJ (2007) The positive correlation between avian species richness and human population density in Britain is not attributable to sampling bias. Global Ecology and Biogeography, 16, 300-304.

Evans KL, Hatchwell BJ, Parnell M, Gaston KJ (In press) Factors influencing colonisation of urban areas: the blackbird Turdus merula as a case study. Biological Reviews

Evans KL, Newson SE, Gaston KJ (2009) Habitat influences on urban avian assemblages. Ibis, 151, 19-39.

Evans KL, van Rensburg BJ, Gaston KJ, Chown SL (2006) People, species richness and human population growth. Global Ecology and Biogeography, 15, 625-636.

Freckleton RP (2002) On the misuse of residuals in ecology: regression of residuals versus multiple regression. Journal of Animal Ecology, 71, 542-545.

Friesen LE, Eagles PFJ, MacKay RJ (1995) Effects of residential development on forest dwelling neotropical migrant songbirds. Conservation Biology, 9, 1408-1414.

Fuller RA, Warren PH, Armsworth PR, Barbosa O, Gaston KJ (2008) Garden bird feeding predicts the structure of urban avian assemblages. Diversity \& Distributions, 14, 131-137.

Fuller RM, Smith GM, Sanderson JM, Hill RA, Thomson AG, Cox R, Brown NJ, Clarke RT, Rothery P, Gerard FF (2002) Countryside Survey 2000 Module 7 Land Cover Map 2000 Final Report CSLCM. Centre for Ecology and Hydrology, Monks Wood.

García-Berthou E (2001) On the misuse of residuals in ecology: testing regression residuals vs the analysis of covariance. Journal of Animal Ecology, 70, 708-711.

Garland T, Ives AR (2000) Using the past to predict the present: confidence intervals for regression equations in phylogenetic comparative methods. American Naturalist, 155, 346-364. 
1 Gaston KJ (2003) The structure and dynamics of geographic ranges. OUP, Oxford.

2 Gaston KJ, Blackburn TM (2000) Pattern and process in macroecology. Blackwell Science Ltd., 3 Oxford.

4 Gaston KJ, Blackburn TM, Gregory RD, Greenwood JJD (1998) The anatomy of the interspecific 5 abundance-range size relationship for the British avifauna: I. Spatial patterns. Ecology Letters, 1, $6 \quad 38-46$.

7 Gonzalez-Abraham CE, Radeloff VC, Hawbaker TJ, Hammer RB, Stewart SI, Clayton MK (2007)

8 Patterns of houses and habitat loss from 1937 to 1999 in northern Wisconsin, USA. Ecological $9 \quad$ Applications, 17, 2011-2023.

10 Grafen A (1989) The phylogenetic regression. Philosophical Transactions of the Royal Society of $11 \quad$ London B, 326, 119-157.

12 Gregory RD, Greenwood JJD, Hagemeijer EJM (1998) The EBCC atlas of European breeding 13 birds: a contribution to science and conservation. Biologia e Conservazione della Fauna, 102, 38$14 \quad 49$.

15 Gregory RD, Gaston KJ (2000) Explanations of commonness and rarity in British breeding birds,

Grimm NB, Faeth SH, Golubiewsk NE, Redman CL, Wu J, Bai X, Briggs JM (2008) Global change and the ecology of cities. Science, 319, 756-760.

Hagemeijer WJM, Blair MJ (1997) The EBCC atlas of European breeding birds: their distribution and abundance. T \& AD Poyser, London.

21 Haines-Young RH, Barr CJ, Black HIJ, Briggs DJ, Bunce RGH, Clarke RT, Cooper A, Dawson FH, Firbank LG, Fuller RM, Furse MT, Gillespie MK, Hill R, Hornung M, Howard DC, McCann T, Morecroft MD, Petit S, Sier ARJ, Smart GM, Stott AP, Stuart RC, Watkins JW (2000) Accounting for nature: assessing habitats in the UK countryside. Department of the Environment Transport and the Regions, London. 
1 Hamer AJ, McDonnell MJ (2008) Amphibian ecology and conservation in the urbanising world: a

2 review. Biological Conservation, 141, 2432-2449.

3 Hanski I (2001) Population dynamic consequences of dispersal in local populations and in meta-

4 populations. In: Dispersal (eds Clobert J, Danchin E, Nichols JD, Dhondt AA), pp. 283-298.

$5 \quad$ Oxford University Press, Oxford.

6 Healy SD, Rowe C (2007) A critique of comparative studies of brain size. Proceedings of the Royal $7 \quad$ Society of London B, 274, 453-464.

Holloway S (1996) Historical atlas of breeding birds in Britain and Ireland. T \& AD Poyser, 9 London.

Hurlbert AH, White EP (2007) Ecological correlates of geographical range occupancy in North American birds. Global Ecology and Biogeography, 16, 764-773.

Iwaniuk AN, Nelson JE (2001) A comparative analysis of relative brain size in waterfowl (Anseriformes). Brain Behavior and Evolution, 57, 87-97.

Iwaniuk AN, Nelson JE (2002) Can endocranial volume be used as an estimate of brain size in birds? Canadian Journal of Zoology, 80, 16-23.

Iwaniuk AN, Nelson JE (2003) Developmental differences are correlated with relative brain size in birds: a comparative analysis. Canadian Journal of Zoology, 81, 1913-1928.

Jiguet F, Gadot A-S, Julliard R, Newson SE, Couvet D (2007) Climate envelope, life history traits and the resilience of birds facing global change. Global Change Biology, 13, 1672-1684.

Jokimäki J, Clergeau P, Kaisanlahti-Jokimäki ML (2002) Winter bird communities in urban

Jokimäki J, Huhta E (2000) Artificial nest predation and abundance of birds along an urban gradient. Condor, 102, 838-847.

Kark S, Iwaniuk A, Schalimtzek A, Banker E (2007) Living in the city: can anyone become an 'urban exploiter'? Journal of Biogeography, 34, 638-651. 
1 Lefebvre L, Gaxiola A, Dawson S, Timmermans S, Rosza L, Kabai P (1998) Feeding innovations

2 and forebrain size in Australasian birds. Behaviour, 135, 1077-1097.

3 Lefebvre L, Whittle P, Lascaris E, Finkelstein A (1997) Feeding innovations and forebrain size in 4 birds. Animal Behaviour, 53, 549-560.

5 Liu J, Daily GC, Ehrlich PR, Luck GW (2003) Effects of household dynamics on resource 6 consumption and biodiversity. Nature, 421, 530-533.

7 Lloret F, Medail F, Brundu G, Camarda I, Moragues E, Rita J, Lambdon P, Hulme PE (2005)

8 Species attributes and invasion success by alien plants on Mediterranean islands. Journal of $9 \quad$ Ecology, 93, 512-520.

10 Luck GW (2007) A review of the relationships between human population density and biodiversity.

11 Biological Reviews, 82, 607-645.

12 Martin TE, Li P (1992) Life-history traits of open-nesting vs cavity-nesting birds. Ecology, 73, 57913592.

14 Martins EP (1999) Estimation of ancestral states of continuous characters: a computer simulation 15 study. Systematic Biology, 48, 642-650.

16 McDonald RI, Kareiva P, Forman RTT (2008) The implications of current and future urbanization 17 for global protected areas and biodiversity conservation. Biological Conservation, 141, 1695$18 \quad 1703$.

19 McKinney ML (2006) Urbanization as a major cause of biotic homogenization. Biological 20 Conservation, 127, 247-260.

21 Mlíkovský J (1989a) Brain size in birds: 1 Tinamiformes through ciconiiformes. Vestnik 22 Ceskoslovenska Spolecnosti Zoologicka, 53, 33-47.

23 Mlíkovský J (1989b) Brain size in birds: 2 Falconiformes through Gaviiformes. Vestnik 24 Ceskoslovenska Spolecnosti Zoologicka, 53, 200-213.

25 Mlíkovský J (1989c) Brain size in birds: 3 Columbiformes through Piciformes. Vestnik 26 Ceskoslovenska Spolecnosti Zoologicka, 53, 252-264. 
1 Mlíkovský J (1990) Brain size in birds: 4 Passeriformes. Acta Societatis Zoologicka

2 Bohemoslovacae, 54, 27-37.

3 Møller AP (2009) Successful city dwellers: a comparative study of the ecological characteristics of

4 urban birds in the Western Palearctic. Oecologia, 159, 849-858.

5 Møller AP, Jennions MD (2002) How much variance can be explained by ecologists and 6 evolutionary biologists? Oecologia, 132, 492-500.

7 Newson SE, Evans KL, Noble DG, Greenwood JJD, Gaston KJ (2008) Use of distance sampling to 8 improve estimates of national population sizes for common and widespread breeding birds in the $9 \quad$ UK. Journal of Applied Ecology, 45, 1330-1338.

10 Owens IPF, Bennett PM (2000) Ecological basis of extinction risk in birds: habitat loss versus 11 human persecution and introduced predators. Proceedings of the National Academy of Sciences $12 \quad U S A, 97,12144-12148$.

13 Paradis E, Baillie SR, Sutherland WJ, Gregory RD (1998) Patterns of natal and breeding dispersal 14 in birds. Journal of Animal Ecology, 67, 518-536.

15 Paradis E, Claude J, Strimmer K (2004) APE: analyses of phylogenetics and evolution in R 16 language. Bioinformatics, 20, 289-290.

17 Partecke J, Schwabl I, Gwinner E (2006) Stress and the city: urbanization and its effects on the 18 stress physiology in European Blackbirds. Ecology, 87, 1945-1952.

19 Phillips BL, Brown GP, Travis JMJ, Shine R (2008) Reid's paradox revisited: The evolution of 20 dispersal kernels during range expansion. American Naturalist, 172, S34-S48.

21 Post E, Forchhammer MC (2008) Climate change reduces reproductive success of an Arctic herbivore through trophic mismatch. Philosophical Transactions of the Royal Society of London

24 Purvis A, Gittleman JL, Cowlishaw G, Mace GM (2000) Predicting extinction risk in declining species. Proceedings of the Royal Society of London B, 267, 1947-1952. 
1 Quinn GP, Keough MJ (2002) Experimental design and data analysis for biologists. Cambridge

2 University Press, Cambridge.

3 Radeloff VC, Stewart SI, Hawbaker TJ, Gimmi U, Pidgeon AM, Flather CH, Hammer RB \&

4 Helmers DP (In press) Housing growth in and near United States protected areas limits their 5 conservation value. Proceedings of the National Academy of Sciences USA.

6

7

8

9

10

11

12

13

14

Rannap R, Lohmus A, Briggs L (2009) Niche position, but not niche breadth, differs in two coexisting amphibians having contrasting trends in Europe. Diversity and Distributions, 15, 692700.

Rasanen K, Hendry AP (2008) Disentangling interactions between adaptive divergence and gene flow when ecology drives diversification. Ecology Letters, 11, 624-636.

Raven MJ, Noble DG, Baillie SR (2007) The Breeding Bird Survey 2006 BTO Research Report 471. British Trust for Ornithology, Thetford.

Riley SPD, Busteed GT, Kats LB, Vandergon TL, Lee LFS, Dagit RG, Kerby JL, Fisher RN, Sauvajot RM (2005) Effects of urbanization on the distribution and abundance of amphibians and invasive species in southern California streams. Conservation Biology, 19, 1894-1907.

Rios RS, Marquis RJ, Flunker JC (2008) Population variation in plant traits associated with ant attraction and herbivory in Chamaecrista fasciculata (Fabaceae). Oecologia, 156, 577-588.

Rodewald AD, Bakermans MH (2006) What is the appropriate paradigm for riparian forest conservation? Biological Conservation, 128, 193-200.

Sanderson FJ, Donald PF, Pain DJ, Burfield IJ, van Bommel FPJ (2006) Long-term population declines in Afro-Palearctic migrant birds. Biological Conservation, 131, 93-105. 
1 Seoane J, Carrascal LM (2007) Interspecific differences in population trends of Spanish birds are

2 related to habitat and climatic preferences. Global Ecology and Biogeography, 17, 111-121.

3 Shugart HH, Patten BC (1972) Niche quantification and the concept of niche pattern. In: Systems analysis and simulation ecology (ed Patten BC), pp. 283-327. Academic Press, New York.

Shultz S, Bradbury R, Evans KL, Gregory R, Blackburn T (2005) Brain size and resource specialisation predict long-term population trends in British birds. Proceedings of the Royal Society, London B, 272, 2305-2311.

Sims V, Evans KL, Newson SE, Tratalos J, Gaston KJ (2008) Avian assemblage structure and domestic cat densities in urban environments. Diversity \& Distributions, 14, 387-399.

Sol D, Bacher S, Reader SM, Lefebvre L (2008) Brain size predicts the success of mammal species

11 introduced into novel environments. American Naturalist, 172, S63-S71.

12 Sol D, Duncan RP, Blackburn TM, Cassey P, Lefebvre L (2005) Big brains, enhanced cognition, 13 and response of birds to novel environments. Proceedings of the National Academy of Sciences USA, 102, 5306-5307.

Stewart JR (2004) Wetland birds in the recent fossil record of Britain and northwest Europe. British Birds, 97, 33-43.

17 Thomas GH (2008) Phylogenetic distributions of British birds of conservation concern. 18 Proceedings of the Royal Society of London B, 275, 2077-2083.

19 Tratalos J, Fuller RA, Evans KL, Davies RG, Newson SE, Greenwood JJD, Gaston KJ (2007) Bird 20 densities are associated with household densities. Global Change Biology, 13, 1685-1695.

UN (2008) World urbanization prospects: the 2007 revision. United Nations, New York. Available at http://wwwunorg/esa/population/publications/wup2007/2007WUP_Highlights_webpdf.

Visser ME, Both C, Lambrechts MM (2004) Global climate change leads to mistimed avian reproduction. Advances in Ecological Research, 35, 89-110. movements of the birds of Britain and Ireland. T \& AD Poyser, London. 
1 Wilcove DS, Wikelski M (2008) Going, going, gone: is animal migration disappearing. PLoS 2 Biology, 6, e188.

3 
Table 1 Variables used to calculate niche breadth and niche position, adapted from the methodology of Gregory \& Gaston (2000).

\begin{tabular}{|c|c|c|}
\hline Variable & Description & Source \\
\hline ALTH & Highest altitude (m) & $\begin{array}{l}\text { ITE's land characteristics database from } 10 \mathrm{~km} \mathrm{x} \\
10 \mathrm{~km} \text { squares (Ball et al., 1983) }\end{array}$ \\
\hline ALTD & Difference between highest and lowest altitude (m) & " \\
\hline RIVE & $\begin{array}{l}\text { Frequency score of rivers (range } 0-0.25 \text { ) from a } \\
5 \times 5 \text { grid overlay of square }\end{array}$ & $"$ \\
\hline RAIN & Average annual monthly rainfall $(\mathrm{mm})$ & $\begin{array}{l}\text { UKCP09 data for } 5 \mathrm{~km} \times 5 \mathrm{~km} \text { squares for } 2006 \\
\text { (http://ukclimateprojections.defra.gov.uk) }\end{array}$ \\
\hline TEMP & Average annual daily temperature $\left({ }^{\circ} \mathrm{C}\right)$ & $"$ \\
\hline CLOUD & $\begin{array}{l}\text { Average annual hourly (or 3-hourly) total cloud } \\
\text { cover }(\%)\end{array}$ & As above but for 2003 \\
\hline CT01 & Sea/estuary & $\begin{array}{l}\text { CEH's LCM } 2000 \text { data base, measured as } \\
\text { percentage of } 1 \mathrm{~km} \text { x } 1 \mathrm{~km} \text { square (Fuller } \text { et al., } \\
\text { 2002) }\end{array}$ \\
\hline СT02 & Inland waters & " \\
\hline CT03 & Beach/flats & " \\
\hline CT04 & Saltmarsh/seaweed & " \\
\hline CT05 & Lowland grass heaths & " \\
\hline CT06 & Pasture/amenity turf & " \\
\hline CT07 & Meadows, verges and semi-natural cropped swards & " \\
\hline CT08 & Marsh/rough grassland & " \\
\hline СT09 & Montane/hill grass & " \\
\hline CT10 & Dwarf shrub/grass moorland & " \\
\hline CT11 & Upland dwarf shrub moorland & " \\
\hline CT12 & Bracken & " \\
\hline CT13 & Lowland heath & " \\
\hline CT14 & Scrub/orchard & " \\
\hline CT15 & Deciduous wood & " \\
\hline CT16 & Evergreen wood & " \\
\hline CT17 & Upland bog & " \\
\hline CT18 & Arable land & " \\
\hline CT19 & Ruderal weeds & " \\
\hline CT22 & Bare ground & " \\
\hline CT23 & Felled forest & " \\
\hline CT24 & Lowland bog & " \\
\hline CT25 & Dwarf shrub/grass heath & " \\
\hline
\end{tabular}


Table 2 Pearson correlations between four urbanisation indices (logarithmically transformed to base ten) of 88 native British bird species. Indices are either the density within urban areas, or the ratio of urban and rural population densities. These indices are calculated when defining urban areas as those in which each of the ten transect sections are urban 6 or suburban or when at least six sections met these criteria. $P<0.0001$ in all cases.

\begin{tabular}{lccc}
\hline & $\begin{array}{c}\log _{10} \text { urban } \\
\text { density_10 sections }\end{array}$ & $\begin{array}{c}\log _{10} \text { urban } \\
\text { density_6 sections }\end{array}$ & $\begin{array}{c}\log _{10} \text { ratio urban to rural } \\
\text { density_10 sections }\end{array}$ \\
\hline $\log _{10}$ urban density_6 sections & 0.978 & - & - \\
$\log _{10}$ ratio urban to rural density_10 sections & 0.896 & 0.846 & - \\
$\log _{10}$ ratio urban to rural density_6 sections & 0.853 & 0.859 & 0.938 \\
\hline
\end{tabular}


Table 3 Multiple regression analyses of relationships between urbanisation indices of British birds and ecological and life history traits in analyses that restricted data to: (a) the six predictors that were available for all 88 species, and (b) the 55 species for which data were available for all ten predictors. For each of the two sets of analyses, model averaged partial $r^{2}$ values are presented when these are $\geq 0.01$ for at least one response variable, together with model averaged parameter estimates. For categorical variables parameter estimates are reported for when the species lacks the focal trait and equal zero when a species exhibits the trait.

(a)

\begin{tabular}{|c|c|c|c|c|c|c|c|c|c|c|c|c|}
\hline \multirow[b]{2}{*}{ response } & \multirow{2}{*}{$\begin{array}{c}\text { \# models in } \\
95 \% \text { confidence } \\
\text { set }\end{array}$} & \multirow{2}{*}{$\begin{array}{c}\text { model } \\
\text { averaged } \\
\text { total } \mathbf{r}^{2}\end{array}$} & \multicolumn{2}{|c|}{ ground-nesting } & \multicolumn{2}{|c|}{ diet_plants } & \multicolumn{2}{|c|}{ diet_inverts } & \multicolumn{2}{|c|}{ migrant } & \multicolumn{2}{|c|}{ range } \\
\hline & & & $\underset{\mathbf{r}^{2}}{\text { partial }}$ & slope & $\underset{\mathbf{r}^{2}}{\text { partial }}$ & slope & $\begin{array}{c}\text { partial } \\
\mathbf{r}^{2}\end{array}$ & slope & $\begin{array}{c}\text { partial } \\
\mathbf{r}^{2}\end{array}$ & slope & $\begin{array}{c}\text { partial } \\
\mathbf{r}^{2}\end{array}$ & slope \\
\hline & 9 & & 0.001 & & 0.079 & & 0.006 & & 0.050 & & 0.233 & \\
\hline $\log _{10}$ & 9 & & 0.002 & +0.0 & 0.069 & -0.6 & 0.003 & & 0.052 & +0 & 0.225 & 01 \\
\hline $\log _{10}$ & 6 & & 0.103 & +0.351 & 0.100 & -0.360 & 0.001 & & 0.010 & +0.097 & 0.000 & 0.000 \\
\hline $\log _{10}$ ratio_10 & 12 & 0.283 & 0.078 & +0.319 & 0.106 & -0.395 & 0.0002 & -0.014 & 0.006 & +0.078 & 0.003 & +0.00002 \\
\hline
\end{tabular}

(b)

\begin{tabular}{|c|c|c|c|c|c|c|c|c|c|c|c|c|c|c|c|c|}
\hline \multirow{2}{*}{ response } & \multirow{2}{*}{$\begin{array}{c}\text { \# models in } \\
95 \% \\
\text { confidence set }\end{array}$} & \multirow{2}{*}{$\begin{array}{c}\text { model } \\
\text { averaged } \\
\text { total } \mathbf{r}^{2}\end{array}$} & \multirow{2}{*}{$\begin{array}{c}\text { ground-I } \\
\text { partial } \\
\mathbf{r}^{2}\end{array}$} & \multirow{2}{*}{$\begin{array}{l}\text { nesting } \\
\text { slope }\end{array}$} & \multicolumn{2}{|c|}{ diet_plants } & \multicolumn{2}{|c|}{ diet_inverts } & \multicolumn{2}{|c|}{ migrant } & \multicolumn{2}{|c|}{$\log _{10}$ dispersal } & \multicolumn{2}{|c|}{$\begin{array}{c}\log _{10} \text { niche } \\
\text { position }\end{array}$} & \multicolumn{2}{|c|}{ relative brain size } \\
\hline & & & & & $\underset{\mathbf{r}^{2}}{\text { partial }}$ & slope & $\underset{\mathbf{r}^{2}}{\text { partial }}$ & slope & $\underset{\mathbf{r}^{2}}{\text { partial }}$ & slope & $\underset{\mathbf{r}^{2}}{\text { partial }}$ & slope & $\underset{\mathbf{r}^{2}}{\operatorname{partial}}$ & slope & $\underset{\mathbf{r}^{2}}{\text { partial }}$ & slope \\
\hline $\begin{array}{l}\log _{10} \\
\text { density_6 }\end{array}$ & 75 & 0.560 & 0.001 & +0.034 & 0.089 & -0.708 & 0.007 & -0.170 & 0.003 & +0.004 & 0.035 & -0.584 & 0.253 & $\begin{array}{l}\text { lin. }-3.617 \\
\text { sq. }-2.095\end{array}$ & 0.009 & $\begin{array}{l}\log _{10} \text { br_vol }+0.042 \\
\log _{10} \text { bo_size }-0.131\end{array}$ \\
\hline $\begin{array}{l}\log _{10} \\
\text { density_10 }\end{array}$ & 94 & 0.480 & 0.004 & +0.107 & 0.070 & -0.649 & 0.005 & -0.152 & 0.001 & +0.027 & 0.042 & -0.680 & 0.184 & $\begin{array}{l}\text { lin. }-2.179 \\
\text { sq. }-2.179\end{array}$ & 0.004 & $\begin{array}{l}\log _{10} \text { br_vol }+0.038 \\
\log _{10} \text { bo_size }-0.079\end{array}$ \\
\hline $\log _{10}$ ratio_6 & 89 & 0.423 & 0.014 & +0.099 & 0.095 & -0.330 & 0.001 & -0.024 & 0.007 & +0.071 & 0.003 & -0.055 & 0.201 & $\begin{array}{l}\text { lin. }-1.893 \\
\text { sq. }-1.394\end{array}$ & 0.002 & $\begin{array}{l}\log _{10} \text { br_vol }+0.020 \\
\log _{10} \text { bo_size }-0.004\end{array}$ \\
\hline $\begin{array}{l}\log _{10} \\
\text { ratio_10 }\end{array}$ & 141 & 0.366 & 0.015 & +0.111 & 0.086 & -0.331 & 0.003 & -0.048 & 0.006 & +0.073 & 0.010 & -0.122 & 0.135 & $\begin{array}{l}\text { lin. }-1.744 \\
\text { sq. }-1.401\end{array}$ & 0.004 & $\begin{array}{l}\log _{10} \text { br_vol }+0.014 \\
\log _{10} \text { bo_size }+0.009\end{array}$ \\
\hline
\end{tabular}


Table 4 Variation in species' traits between British avian species that are present and absent in at least one urbanised $1 \mathrm{~km} \times 1 \mathrm{~km}$ grid cell.

\begin{tabular}{lllll}
\hline \multicolumn{1}{c}{ trait } & \multicolumn{1}{c}{ urban definition } & \multicolumn{2}{c}{ mean trait value } & \multicolumn{2}{c}{ T - test } \\
\hline range size (\# of & 10 urban transect sections & $1427 \pm 39, \mathrm{n}=56$ & $1198 \pm 72, \mathrm{n}=32$ & $t=-2.80, P=0.007$ \\
occupied 50km squares) & & & & \\
" & 6 urban transect sections & $1377 \pm 40, \mathrm{n}=70$ & $1215 \pm 97, \mathrm{n}=18$ & $t=-1.54, P=0.140$ \\
natal dispersal $\left(\log _{10}\right)$ & 10 urban transect sections & $0.97 \pm 0.05, \mathrm{n}=43$ & $1.24 \pm 0.08, \mathrm{n}=12$ & $t=2.41, P=0.020$ \\
" & 6 urban transect sections & $1.02 \pm 0.05, \mathrm{n}=48$ & $1.15 \pm 0.09, \mathrm{n}=7$ & $t=0.95, P=0.350$ \\
annual fecundity & 10 urban transect sections & $7.63 \pm 0.44, \mathrm{n}=56$ & $6.66 \pm 0.55, \mathrm{n}=32$ & $t=1.36, P=0.170$ \\
" & 6 urban transect sections & $7.31 \pm 0.39, \mathrm{n}=70$ & $7.11 \pm 0.71, \mathrm{n}=18$ & $t=0.24, P=0.810$ \\
\hline
\end{tabular}


Figure 1. The relationships between: (a) European range size and urban density; (b) European range size and the ratio of urban and rural densities; (c) logarithmically transformed niche position and urban density; and (d) logarithmically transformed niche position and the ratio of urban and rural densities of British birds. Urban areas are defined as $1 \mathrm{~km}$ x $1 \mathrm{~km}$ squares in which at least six of the ten $200 \mathrm{~m}$ transect sections are urban or suburban. Grey lines indicate the model averaged predicted values whilst holding other continuous variables at their mean values and categorical variables at their most frequently observed values. Defining urban areas as those squares in which each of the transect sections are urban or suburban does not substantially alter the results (Table 2).

a)

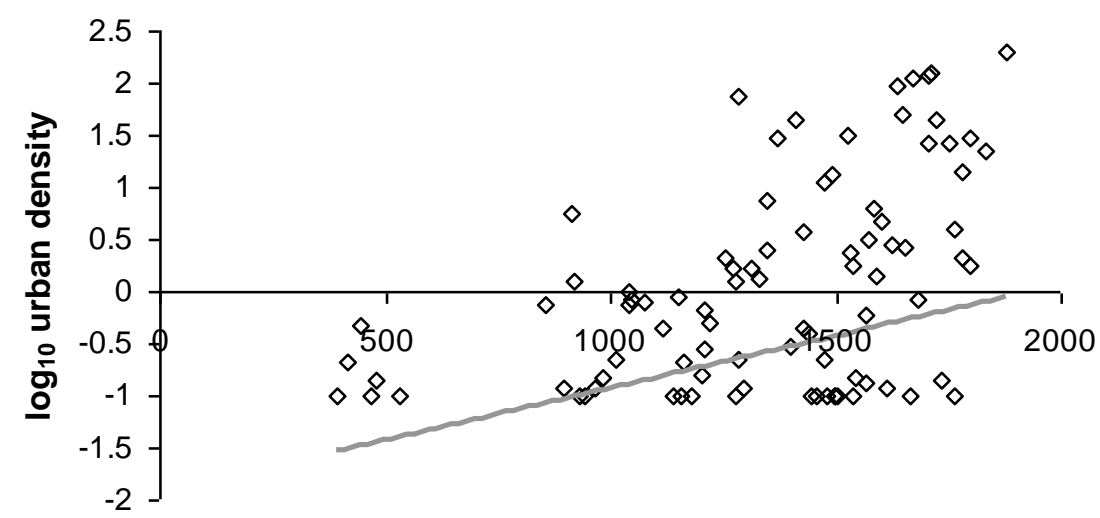

number of occupied European $50 \mathrm{~km}$ x $50 \mathrm{~km}$ squares

c)

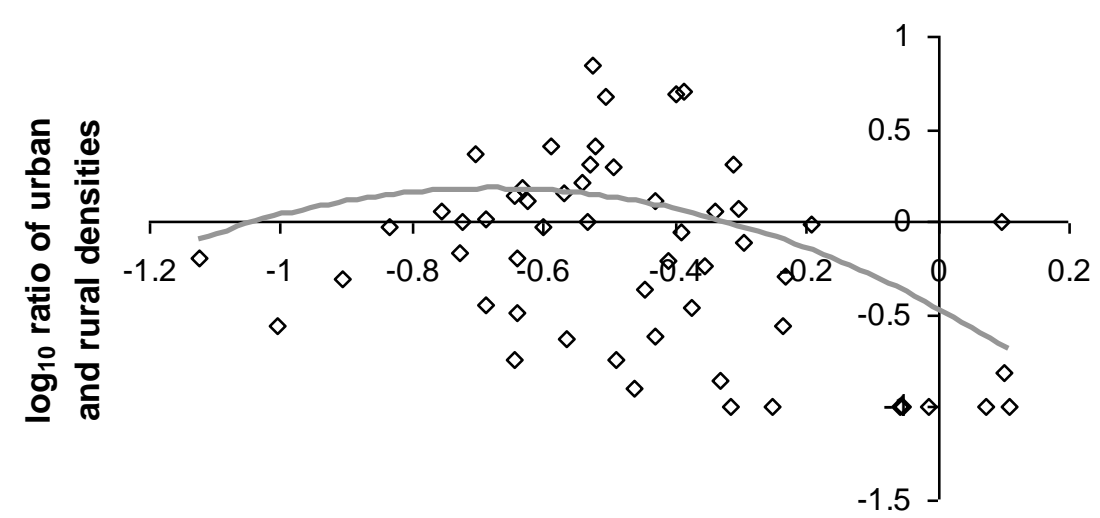

$\log _{10}$ niche position

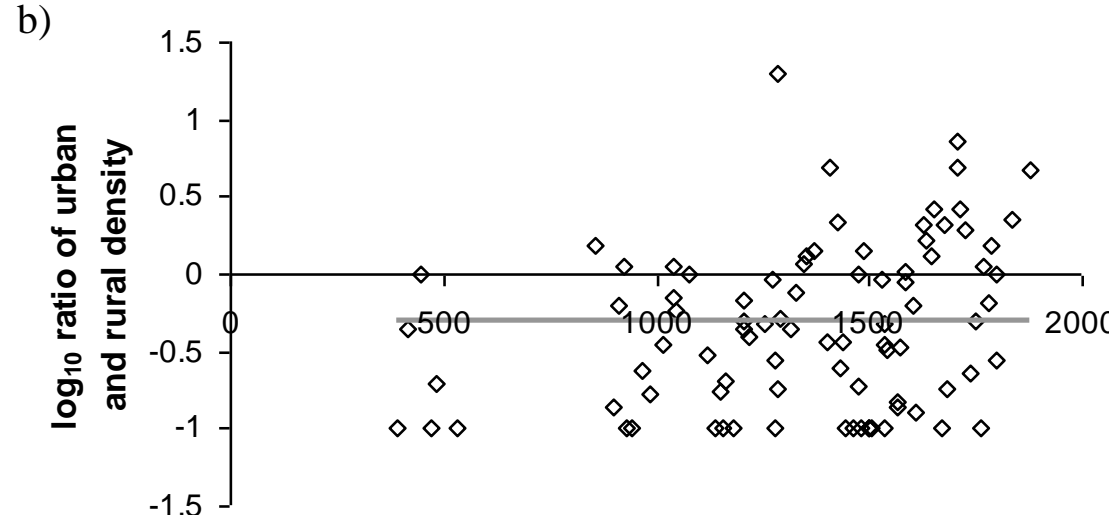

number of occupied European $50 \mathrm{~km}$ x $50 \mathrm{~km}$ squares

d)

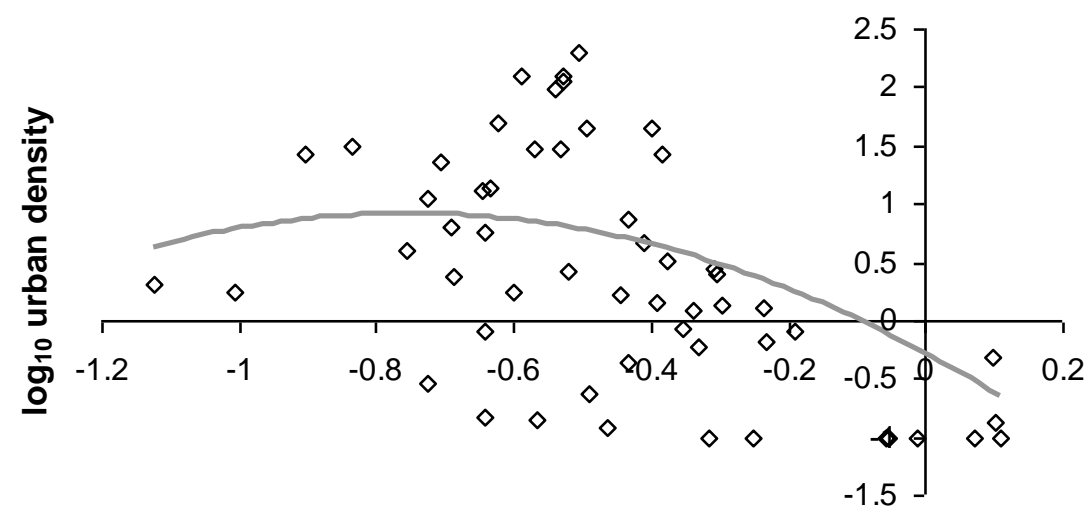

$\log _{10}$ niche position 